\title{
Assessment of primary schools' environment in Erbil city
}

Accepted: 5/9/2012

\begin{abstract}
Salih A. Abdulla *
Badia Mahammad Najib *

Namir Ghanim Al-Tawil **

Abstract

Background and objective: Healthy school environment is one of the main determinants of students' health in order to maximize the benefit from the educational programs. This study was aimed to assess the primary school environment in Erbil city.

Methods: A cross-sectional study was conducted in 50 primary schools in Erbil city out of 242 schools through the academic year 2010-2011. Data were collected using a questionnaire constructed by the researchers which included general information, area around the school, school environment, class-room and school canteen.

Results: Most of the primary schools were located near the main street, nearly all $(98 \%)$ the streets leading to the schools were paved. In contrast, thirty one (62\%) schools had been exposed to a pollution source, mainly noise $(54.84 \%)$ and garbage $(45.16 \%)$ pollution. The majority of the schools had standard school fencing, school yard, and garbage container, and only $8(16 \%)$ of them had available/standard school ground. The study showed that nearly half of the schools had appropriate classrooms, lighting, and majority of them had adequate desks, appropriate blackboards and clean classrooms, while ventilation and age appropriate desks were partially available. The amount of chlorine in water was not tested. There is lack of materials in the first aid kits. Canteens were available, but not standard and the working staff did not have the health certificate.
\end{abstract}

Conclusion: School environment in Erbil city is not optimum.

Keywords: Assessment, School, Environment, Erbil

\section{Introduction}

All members of the school community need clean air to breathe, clean water to drink, a safe place for recreation, a safe way to travel to school to avoid accidents, and protection from extreme temperatures and ultraviolet radiation. A safe and healthy physical environment requires a good location and safe buildings; protection from excessive noise; natural light; clean indoor air and water; a healthy outdoor environment; and healthy school-related activities including safe management and maintenance practices, use of non-toxic cleaning supplies, careful use of pesticides, vector control, and use of non-toxic art supplies ${ }^{1}$. With more than 150,000 children spending many hours a day in more than 200 primary schools in Erbil city, the school environment is of special importance to children's health and development. Schools grapple with a wide variety of environmental problems, a high occupant density, and limited resources to prevent and address building, and health and safety issues (personal communication with Ahmed Majid, head of planning in directorate of education in Erbil city, at January 13, 2010). Physical school environment has a strong influence on children's health for several reasons. First, the environment is one of the primary determinants of children's health: contaminated water supplies can result in diarrheal diseases; air pollution can worsen acute respiratory infections and trigger asthma attacks; and exposure to lead, arsenic,

*Department of Pediatrics/Community health Nursing, College of Nursing, Hawler Medical University, Erbil, Iraq.

**Department of Community Medicine, College of Medicine, Hawler Medical University, Erbil, Iraq. 
solvents, and pesticides can cause a variety of health effects and even death. Second, children may be more susceptible to the adverse health effects of chemical, physical, and biological hazards than adults. Reduced immunity, immaturity of organs and functions, and rapid growth and development can make children more vulnerable to the toxic effects of environmental hazards than adults. Third, children's behavioral patterns are distinctively different from adults and place them at risk from exposure to environmental threats that adults may not face ${ }^{1}$. School health service aims to provide promotive, preventive and curative services which include health education and provision of a healthful school environment ${ }^{2}$. Up to researchers' knowledge, no publication study had been carried out previously in Erbil to assess the school environment. The aim of this study is to assess the primary schools environment in Erbil city.

\section{Methods}

A cross-sectional study was conducted in 50 primary schools in Erbil city out of 242 schools through the academic year 2010-2011. A purposive (non - probability) sampling was used for this study. Prior to the data collection, permission to conduct this study was taken from the General Directorate of Education/Ministry of Education, and from the World Health Organization (WHO) to use the questionnaire that had been used by the WHO team during the 2008 survey which was conducted in eight governorates of Iraq (Erbil was excluded $)^{3}$. Data were collected by one of the researchers using a questionnaire that was adapted from WHO questionnaire. The tool was composed of five parts as follows: 1.General information, 2. Area around the school, 3. School environment, 4. Class -rooms and 5. School canteen. General information about primary schools was taken which included name of the school. Information on area around the school included: the distance between schools and main streets, street leading to school, pollution sources near the school, type of pollution sources, accessibility of health center, and causes to inaccessibility. School environment data included: the school fence, school yard, school yard to number of student (each student require 1-1.5 square meter) ${ }^{3}$, school cleanliness (as assessed by the researcher), power source, availability of garbage containers, daily disposal of wastes, drinking water source, testing for chlorine residual, adequate taps (fifty student should have one tap) ${ }^{3}$, adequate number of toilets (one toilet for every 25 students) ${ }^{3}$, sanitary conditions, presence of sewage system, presence of insect and rodent control, health records in school, availability of first aid kit, availability of basic material in first aid kit, and school grounds (if the school ground present and cared, it was considered standard while if it is present but not cared it was considered not standard $)^{3}$. Classroom items included: the classroom area (each student require one square meter) ${ }^{3}$, lighting (as assessed by the researcher), ventilation, number of desks, blackboard, chalk, and classroom cleanliness. School canteen items included: availability of canteen (standard canteen is defined as being built by bricks and cement, and its floor is easily cleaned), quality of food, presence of valid medical cards of workers, presence of health education certificate of workers, and presence of another source that sells food items to the school. Data were analyzed using the Statistical Package for Social Sciences (SPSS version 11.5). Frequencies and percentages were calculated.

\section{Results}

Results showed that all the fifty schools were located near the main street. Nearly all $(98 \%)$ of the streets leading to the schools were paved. Thirty one (62\%) schools had been exposed to a pollution source; the main sources of pollution were noise $(54.84 \%)$ and garbage $(45.16 \%)$. Table 1 Majority of schools had standard school fence, school yard, and garbage containers while only $8(16 \%)$ of them had 
available/standard school ground. Regarding school yard to number of students, majority of them were adequate and most of them were clean. The source of drinking water of majority of schools was from tap water (state network). More than half of schools had first aid kits Table 2 . Table 3 show that nearly half of the schools had appropriate classrooms, lighting, majority of them had adequate desks, appropriate blackboard and clean classrooms, while ventilation and age appropriate desks were partially appropriate. Majority of schools had non standard canteens and nearly half of the schools had another source that sells food items at the school, and more than half of canteen workers had no medical examination card. Table 4

Table 1: Distribution of schools by presence of pollution

\begin{tabular}{|c|c|c|c|}
\hline \multicolumn{2}{|c|}{ Items } & Frequency & Percentage \\
\hline \multicolumn{4}{|c|}{$\begin{array}{l}\text { Presence of pollution } \\
\text { sources near the school }\end{array}$} \\
\hline \multicolumn{2}{|c|}{ Yes } & 31 & 62 \\
\hline \multicolumn{2}{|l|}{ No } & 19 & 38 \\
\hline \multicolumn{2}{|c|}{ Total } & 50 & 100 \\
\hline \multicolumn{4}{|c|}{$\begin{array}{l}\text { Type of pollution } \\
\text { sources }(n=31)\end{array}$} \\
\hline \multicolumn{2}{|c|}{ Noise } & 17 & 54.84 \\
\hline \multicolumn{2}{|c|}{ Garbage } & 14 & 45.16 \\
\hline \multicolumn{2}{|c|}{ Total } & 31 & 100 \\
\hline \multicolumn{4}{|c|}{$\begin{array}{l}\text { Table 2: Distribution of } \\
\text { environmental variables }\end{array}$} \\
\hline No. & Items & Frequency & $\begin{array}{l}\text { Percentage } \\
\mathrm{N}=50\end{array}$ \\
\hline \multirow[t]{3}{*}{1} & $\begin{array}{l}\text { School fence } \\
\text { Available/Standard }\end{array}$ & 40 & 80 \\
\hline & Available/Non standard & 9 & 18 \\
\hline & Not available & 1 & 2 \\
\hline \multirow[t]{3}{*}{2} & $\begin{array}{l}\text { School yard } \\
\text { Available/Standard }\end{array}$ & 29 & 58 \\
\hline & Available/ Non standard & 21 & 42 \\
\hline & Not available & 0 & 0.00 \\
\hline
\end{tabular}

3 School yard to

number of students

$\begin{array}{lll}\text { Adequate } & 45 & 90\end{array}$

$\begin{array}{lll}\text { Inadequate } & 5 & 10\end{array}$

4 School cleanliness

Clean $\quad 48 \quad 96$

$\begin{array}{lll}\text { Not clean } & 2 & 4\end{array}$

5 Power source

$\begin{array}{lll}\text { Regular state network } \quad 49 & 98\end{array}$

Network within the area 1

$\begin{array}{lll}\text { Private generator } & 0 & 0.00\end{array}$

6 Availability of

garbage containers

Available/Standard

46

92

Available/ Non

standard

8

0.00

7 Daily disposal of waste

Yes

No

34

66

8 Drinking water source

Tap water/state

network

Protected

Unprotected

9 Testing water for

chlorine residual.

Yes

10 Adequate taps

Yes

No

Not available

11 Standard taps

Yes

No

12 Adequate number of Toilets

Yes

No

Not available

2

4

0.00

13 Sanitary conditions of toilets

good

bad

14 Presence of sewage system

Yes

No

$\begin{array}{ll}20 & 40 \\ 30 & 60\end{array}$

24

0.00

40
60

\section{0}

$\begin{array}{ll}15 & 30 \\ 35 & 70\end{array}$

24
76
0.00

$\begin{array}{ll}8 & 16 \\ 42 & 84\end{array}$

$45 \quad 90$ 


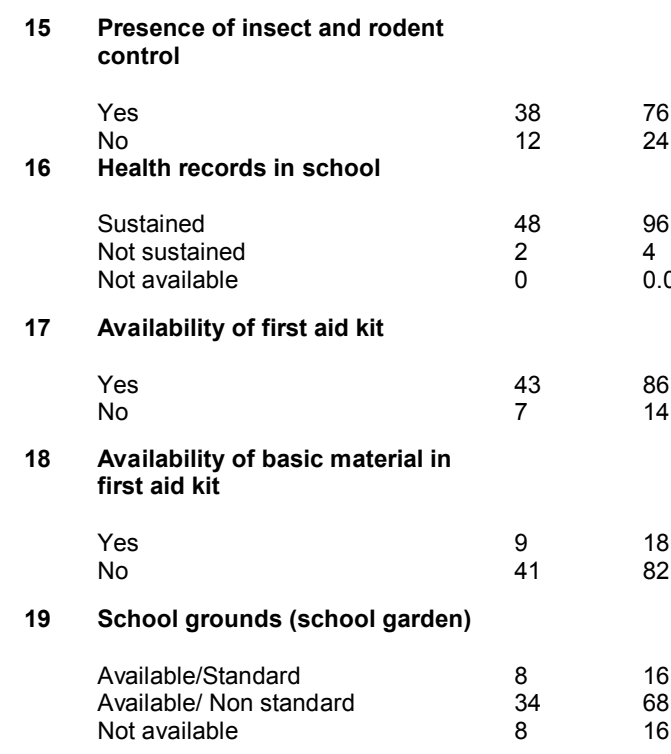

Table 4: Distribution of schools by school canteen variables

\begin{tabular}{|c|c|c|c|}
\hline No. & Items & Frequency & Percentage \\
\hline \multirow[t]{5}{*}{1} & Canteen & & \\
\hline & Available/Standard & 2 & 4 \\
\hline & $\begin{array}{l}\text { Available/ Non } \\
\text { standard }\end{array}$ & 45 & 90 \\
\hline & Not available & 3 & 6 \\
\hline & Total & 50 & 100 \\
\hline \multirow[t]{4}{*}{2} & $\begin{array}{l}\text { Food at canteen } \\
\text { complies with } \\
\text { health conditions }\end{array}$ & & \\
\hline & Yes & 43 & 91.4 \\
\hline & No & 4 & 8.6 \\
\hline & Total & 47 & 100 \\
\hline \multirow[t]{4}{*}{3} & $\begin{array}{l}\text { Do canteen work- } \\
\text { ers carry medical } \\
\text { examination card? }\end{array}$ & & \\
\hline & Yes & 21 & 44.7 \\
\hline & No & 26 & 55.3 \\
\hline & Total & 47 & 100 \\
\hline
\end{tabular}

Table 3: Distribution of schools by classroom variables

\begin{tabular}{|c|c|c|c|}
\hline No. & Items & Frequency & Percentage \\
\hline 1 & $\begin{array}{l}\text { Classroom } \\
\text { Appropriate } \\
\text { Partially appropriate } \\
\text { Inappropriate }\end{array}$ & $\begin{array}{l}24 \\
25 \\
1\end{array}$ & $\begin{array}{l}48 \\
50 \\
2\end{array}$ \\
\hline 2 & $\begin{array}{l}\text { Lighting } \\
\text { Adequate } \\
\text { Inadequate }\end{array}$ & $\begin{array}{l}25 \\
25\end{array}$ & $\begin{array}{l}50 \\
50\end{array}$ \\
\hline 3 & $\begin{array}{l}\text { Ventilation } \\
\text { Appropriate } \\
\text { Partially appropriate } \\
\text { Inappropriate }\end{array}$ & $\begin{array}{l}14 \\
35 \\
1\end{array}$ & $\begin{array}{l}28 \\
70 \\
2\end{array}$ \\
\hline 4 & $\begin{array}{l}\text { Desks } \\
\text { Adequate } \\
\text { Inadequate }\end{array}$ & $\begin{array}{l}47 \\
3\end{array}$ & $\begin{array}{l}94 \\
6\end{array}$ \\
\hline 5 & $\begin{array}{l}\text { Age appropriate } \\
\text { desks } \\
\text { Appropriate } \\
\text { Partially appropriate } \\
\text { Inappropriate }\end{array}$ & $\begin{array}{l}7 \\
43 \\
0\end{array}$ & $\begin{array}{l}14 \\
86 \\
0.00\end{array}$ \\
\hline 6 & $\begin{array}{l}\text { Blackboard } \\
\text { Appropriate } \\
\text { Partially appropriate } \\
\text { Inappropriate }\end{array}$ & $\begin{array}{l}35 \\
15 \\
0\end{array}$ & $\begin{array}{l}70 \\
30 \\
0.00\end{array}$ \\
\hline 7 & $\begin{array}{l}\text { Chalk } \\
\text { Regular } \\
\text { Oil } \\
\text { Others }\end{array}$ & $\begin{array}{l}8 \\
42 \\
0\end{array}$ & $\begin{array}{l}16 \\
84 \\
0.00\end{array}$ \\
\hline 8 & $\begin{array}{l}\text { Classroom } \\
\text { cleanliness } \\
\text { Clean } \\
\text { Not clean }\end{array}$ & $\begin{array}{l}48 \\
2\end{array}$ & $\begin{array}{l}96 \\
4\end{array}$ \\
\hline
\end{tabular}

4 Do canteen work-

ers carry the health education certificate?

$\begin{array}{lll}\text { Yes } & 0 & 0.00 \\ \text { No } & 47 & 100\end{array}$

No

Total

$47 \quad 100$

5 Is there another source that sells food items at the school?

$\begin{array}{lll}\text { Yes } & 25 & 50 \\ \text { No } & 25 & 50 \\ \text { Total } & \mathbf{5 0} & \mathbf{1 0 0}\end{array}$

\section{Discussion}

Maintaining a healthy school environment is critical to the success of students. A healthy school environment includes safeguarding the rights of students, faculties, staffs, and maintaining a safe work environment and a healthy atmosphere ${ }^{4}$. This study showed that more than half of the schools had been exposed to a pollution source. The main sources of pollution were noise and garbage. A recent study by Evans \& Maxwell (1997) identified a link between chronic noise exposure and reading deficits ${ }^{5}$. The present study showed that majority of schools had standard school fence, school yard, and garbage containers, while only $8(16 \%)$ of them had available/standard school 
ground. The study showed that the school yard area was adequate in the majority of schools and most of them were clean, while a study conducted on 147 Iraqi primary schools by WHO (2009) about student's health status and environmental assessment demonstrated that the percentage of standard playground was $(53.7 \%)^{3}$ knowing that the above mentioned study didn't include Erbil schools. There has been a dramatic increase in playground related injuries over the past two decades. According to the United States Consumer Product Safety Commission (CPSC) statistics, nearly 200,000 playground related injuries requiring emergency room visits occurs each year ${ }^{6}$. The present study showed that the source of drinking water of majority of schools was from tap water (state network). These results are similar to the results of a study done by WHO Iraq survey ${ }^{3}$. First aid kits are essential in routine daily life as there are chances for accidents to occur when people least expect them ${ }^{7}$. The present study showed that majority of schools had sustained health records and first aid kits. These results were similar to a study conducted by WHO (2009) which demonstrated that the percentage of sustained health records was $79 \%$ and first aid kits was $64 \%{ }^{3}$. A study done by Omolo (2010) in kisumu east and west districts, Kenya, demonstrated that $(96.6 \%)$ of schools had first aid kits ${ }^{7}$. The present study showed that half of schools had adequate lighting, more than half of the schools had partially adequate ventilation and most of schools had clean classrooms. These results are similar to results of a study done by Adegbenro (2007) which demonstrated that the majority of the classrooms $(80 \%)$ were not over-crowded and the rooms were adequately ventilated ${ }^{8}$. Results of the present study indicated that majority of schools had available/non standard canteens. A healthy canteen was defined as one that was safe, clean, profitable and providing a range of high nutritional value foods ${ }^{9}$.

\section{Conclusion}

The study concluded that pollution sources near the schools, testing water for chlorine residual, adequate taps, adequate number of toilets, availability of basic material in first aid kit, canteen workers carry the health education certificate in Erbil city were not optimum.

\section{Recommendations}

Research and further studies should be conducted in Erbil governorate regarding other aspects of school health program such as assessment of head teacher's knowledge about school health program, prevalence of head lice among primary school children, and knowledge and practice of primary school teachers toward dental caries.

\section{References}

1. WHO, The Physical School Environment: An Essential Component of a Health-Promoting School. Geneva, 2004

2. Muthu, VK editors. The Short Book of Public Health. India: Jaypee Brothers, 2005.

3. WHO, Health promoting schools project: student's health status and environmental assessment at primary schools [Internet] 2009 [cited 2010 June 28] Available from: http://www.emro.who.int/iraq/ pdf/sh_report_ar.pdf

4. National Association of School, Indoor air quality [Internet]. 2000 [cited 2010 June 13] Available from:http://www.nasn.org/positions indoorairquality.htm

5. Evans GW, Maxwell L., Chronic noise exposure and reading deficits: The mediating effects of language acquisition. Environment and Behavior 1997; 29(5): 638-56

6. National program for Program Safety. Playground Safety Tips, [Internet], 2001; [cited 2010 Feb 22] Available from: http:/ www. uni. edu/ Playground/ Tips/SAFE/fallsurf_guidelines. htm

7. Omolo D. An assessment of the implementation of safety policies in public secondary schools in kisumu east and west districts, Edu. Res 2010; 1 (11): $637-49$

8. Adegbenro CA Effect of a school health program on ensuring safe environments for primary school children. J R Soc Health 2007; 127(1): 29-32.

9. Puts K, Mattrow J. Healthy Primary School Canteens Aust. J. Prim. Health 2000; 6(1): 111- 120 